\title{
Protoporphyrin IX Induces a Necrotic Cell Death in Human THP-1 Macrophages through Activation of Reactive Oxygen Species/c-Jun N-Terminal Protein Kinase Pathway and Opening of Mitochondrial Permeability Transition Pore
}

\author{
Haobo Xua,b Yan Suna,b Yun Zhang ${ }^{\mathrm{a}}$ Wei Wang ${ }^{\mathrm{a}}$ Juhua Dan ${ }^{\mathrm{b}}$ Jianting Yao \\ Haibo Chen ${ }^{a}$ Fang Tian ${ }^{a}$ Xin Sun ${ }^{a, b}$ Shuyuan Guo ${ }^{a}$ Zhen Tian ${ }^{b}$ Ye Tiana,b
}

aDivision of Cardiology, the First Affiliated Hospital, Cardiovascular Institute, Harbin Medical University, Harbin, bDepartment of Pathophysiology, the State-Province Key Laboratories of BiomedicinePharmaceutics of China, Key Laboratory of Cardiovascular Research, Ministry of Education, Harbin, China

\section{Key Words}

Protoporhyrin IX $\bullet$ Macrophage $\bullet$ Necrosis $\bullet$ Reactive oxygen species $\bullet \mathrm{c}$-Jun $\mathbf{N}$-terminal protein kinase $\cdot$ Mitochondrial permeability transition pore

\begin{abstract}
Background: Protoporphyrin IX (PpIX) and its derivatives are widely used in photodynamic therapy (PDT) to kill cancer cells. Studies showed that the application of these drugs could cause systemic toxic effects in human. However, the molecular pathways involved in PpIXinduced cytotoxicity are not well-defined. Macrophages represent the primary system for protecting tissues from toxicants and initiating the resolution of inflammation. Thus, this study aims to investigate the toxicity of PpIX on macrophages and provide strategies to prevent the toxic effects. Methods: THP-1 macrophages were incubated with PpIX and cell death was measured by MTT assay and Annexin V-PI staining. Intracellular reactive oxygen species (ROS) were evaluated by 2', 7'-Dichlorodihydrofluorescin diacetate (DCFH-DA) and MitoSOX ${ }^{\circledR}$ Red staining and mitochondrial membrane potential $\left(\Delta \Psi_{\mathrm{m}}\right)$ was detected by tetramethylrhodamine methyl ester (TMRM) staining. Mitogen-activated protein (MAP) kinase activation was assayed by western blotting. Mitochondrial permeability transition pore (mPTP) opening was measured by calcein loading $/ \mathrm{Co}^{2+}$ quenching technique and evaluating the release of mitochondrial content. Results: PpIX reduced cell viability in a dose- and time-dependent manner. The cell death was characterized by increasing PI-positive cells, ATP depletion, LDH releasing and rapid $\Delta \Psi \mathrm{m}$ loss favoring necrotic features. In addition, PpIX successively induced ROS production, c-Jun N-terminal protein kinase (JNK) activation and mPTP opening. ROS
\end{abstract}


scavengers, N-acetylcysteine (NAC) and deferoxamine (DFX), JNK inhibitor, SP600125, and mPTP inhibitor, cyclosporin A (CsA), all significantly rescued this cell death. Furthermore, mPTP opening was directly regulated by ROS/JNK pathway. Conclusion: PpIX induces a necrotic cell death in THP-1 macrophages through ROS production, JNK activation, and mPTP opening. It is tempting to speculate that blocking the pathways involved in the cytotoxic effects of PpIX will alleviate its side effects.

Copyright $\odot 2014$ S. Karger AG, Basel

\section{Introduction}

Protoporphyrin IX, a heme precursor, binds to mitochondrial translocator protein (TSPO) and is transported to mitochondria to participate in heme metabolism [1]. Application of porphyrin derivatives causes massive porphyrins accumulation in cancer cells [2]. Because of this character, PpIX and its derivatives are now applied extensively in photodynamic therapy (PDT) and sonodynamic therapy (SDT) to enhance light- and ultrasound-induced cytotoxicity $[3,4]$. It has been reported that, after intravenous administration of porphyrin derivatives, the maximum serum concentration would reach $40 \mu \mathrm{g} / \mathrm{ml}$ in patients and it could cause systemic toxic effects such as anemia, liver function abnormality, gastrointestinal toxicities, cardiac disorders and et al. [5-7]. Moreover, patients with erythrohepatic protoporphyria or siderblastic anemia who have excessive PpIX accumulation have similar symptoms [8]. Consistent with these, studies in vitro have indicated that PpIX could induce cell death. For instance, in sarcoma 180 cells, PpIX caused cell death with characteristics of apoptosis [9]. PpIX can interact with p53 protein and induce human colon cancer cell apoptosis in both p53-dependent and -independent manners [10]. It was also demonstrated that PpIX could directly cause human osteoblast-like cell necrosis [11]. However, despite the reported PpIX toxicity to cells, the detailed mechanisms are still not clear.

Cells die primarily by apoptosis or necrosis [12]. Apoptosis is an ordered and regulated process, yielding the characteristic morphological features of DNA fragmentation, plasma membrane blebbing, and the formation of apoptotic bodies. In contrast, necrosis has traditionally been regarded as a passive and unregulated form of cell death occurring in response to toxicants and physical injury with morphology of extensive mitochondrial swelling, cytoplasmic vacuolation, and loss of plasma membrane integrity. Nevertheless, studies over the past decade have demonstrated that a significant portion of necrotic cell death also involve elaborate molecular circuitry [13].

Reactive oxygen species (ROS) refers to a group of oxygen centered free radicals such as superoxide anion, hydroxyl radicals and hydrogen peroxide [14]. It is known that the disturbed cell redox status and/or impaired antioxidant defense systems induces a cellular oxidative stress, leading to various biological consequences, including apoptotic or necrotic cell death $[15,16]$. c-Jun N-terminal protein kinase (JNK), an important member of the mitogen-activated protein (MAP) kinase family, is closely associated with oxidative stress-mediated cell death [17]. The involvement of JNK in apoptosis has been widely studied. Recently, the role of JNK activation in necrosis is also highlighted. It was reported that excessive ROS production could lead to sustained JNK activation by inhibiting MAP kinase phosphatases in TNF- $\alpha$-induced necrosis [18]. Also, JNK promotes poly(ADP-ribose) polymerase-1 (PARP-1) over-activation in $\mathrm{H}_{2} \mathrm{O}_{2}$-induced mouse embryonic fibroblasts necrosis [19].

Mitochondria appear to play a central role in the induction of cell death [20]. The critical mitochondrial event in necrosis is the opening of the mitochondrial permeability transition pore (mPTP) in the inner membrane [21]. mPTP is primarily composed of the adenine nucleotide transporter (ANT), cyclophilin D (CypD), and voltage-dependent anion channel (VDAC). Opening of the mPTP causes massive inflow of water into the solute-rich matrix, mitochondrial swelling, dissipation of the mitochondrial membrane potential $(\Delta \Psi \mathrm{m})$ and ATP depletion. Recently, it has been documented that BNIP3, Bax and p53 could modulate mPTP opening in primary necrosis [22-24]. 


\section{Cellular Physiology $\quad$ Cell Physiol Biochem 2014;34:1835-1848 \begin{tabular}{ll|l} 
and BiOchemistry & $\begin{array}{l}\text { DOI: 10.1159/000366383 } \\
\text { Published onlıne: November 21, } 2014\end{array}$ & $\begin{array}{l}\text { C 2014 S. Karger AG, Basel } \\
\text { www.karger.com/cpb }\end{array}$ \\
\cline { 2 - 3 }
\end{tabular} Xu et al.: PpIX Induces Necrosis in Macrophages Through ROS/JNK Pathway and mPTP Opening}

To the best of our knowledge, the toxicity of PpIX on macrophages as well as the cell death signaling pathway is not reported yet. As critical cellular components of nonspecific host defense, macrophages represent the primary system for protecting tissues from toxicants, initiating inflammation resolution and wound healing [25]. The survival of macrophages is closely related to the alleviation and aggravation of PpIX-induced side effects. Thus, in this study, the toxicity of PpIX on human THP-1 macrophages is investigated. We address the questions which type of cell death is PpIX induced in macrophages and what are the molecular events involved in the cell death. Here, we report that PpIX induces a necrotic cell death in human THP-1 macrophages through the following processes: ROS production, JNK activation, mPTP opening, and subsequently mitochondrial dysfunction.

\section{Materials and Methods}

\section{Chemicals}

Protoporphyrin IX (PpIX), phorbol-12-myristate-13-acetate (PMA), staurosporine (Sts), cyclosporin A (CsA), 3-(4,5-dimethylthiazol-2-yl)-2,5-diphenyltetrazolium bromide (MTT), N-acetylcysteine (NAC), and cobalt chloride $\left(\mathrm{CoCl}_{2}\right)$ were purchased from Sigma Chemical Company (St Louis, MO, USA). Deferoxamine (DFX), Ac-DEVD-CHO, z-VAD-fmk, SP600125, SB203580, U0126 were obtained from Santa Cruz Biotechnology (Santa Cruz, CA, USA). All fluorescent dyes, including Hoechst 33342, tetramethylrhodamine methyl ester (TMRM), MitoSOX ${ }^{\circledR}$ Red, 2', 7'-Dichlorodihydrofluorescin diacetate (DCFH-DA) and calceinAM were from Molecular Probes (Invitrogen, CA, USA). All products for cell culture were purchased from Hyclone Laboratories, Inc. (HyClone, Logan, UT, USA).

\section{Cell Culture and In Vitro Experimental Protocols}

Human THP-1 cells (ATCC, Rockefeller, MD, USA) were cultured in RPMI 1640 medium containing $10 \%$ fetal bovine serum (FBS) with $20 \mu \mathrm{g} / \mathrm{ml}$ penicillin and $20 \mu \mathrm{g} / \mathrm{ml}$ streptomycin at $37^{\circ} \mathrm{C}$ and $5 \% \mathrm{CO}_{2}$. Before experiments, THP-1 cells were treated with $10 \mathrm{ng} / \mathrm{ml}$ PMA to differentiate into macrophages for $48 \mathrm{~h}$. PpIX was dissolved in $10 \mathrm{mM} \mathrm{NaOH}$ and stored at $4{ }^{\circ} \mathrm{C}$ in dark. Significant $\mathrm{pH}$ change in cell culture medium as well as cell death was not detected after adding $10 \mathrm{mM} \mathrm{NaOH}$ (final concentration 1\%). For analysis of cellular toxicity, cells were incubated with PpIX for indicated time at $37^{\circ} \mathrm{C}$ in a $\mathrm{CO}_{2}$ incubator in the dark protected from light irradiation. Chemical agents such as NAC, DFX (dissolved in PBS), SB203580, SP600125, U0126 and CsA (dissolved in DMSO, less than 0.1\%) were added $1 \mathrm{~h}$ before stimulated with PpIX.

\section{Cell survival by MTT assay}

Effect of PpIX on cell viability was determined by MTT assay. Macrophages $\left(1 \times 10^{5} /\right.$ well) in 96 well plate were exposed to PpIX (5-20 $\mu \mathrm{M})$ in RMPI 1640 medium for indicated time. $20 \mu \mathrm{l}$ of MTT (final concentration: $0.5 \mathrm{mg} / \mathrm{ml}$ ) was added to each well till the completion time and the cells were further incubated for $4 \mathrm{~h}$ at $37^{\circ} \mathrm{C}$. Afterwards, the culture medium was replaced with $200 \mu \mathrm{l}$ DSO and the absorbance was measured at $490 \mathrm{~nm}$ in a microplate reader (Biotek ELx800).

\section{Sub-cellular localization of PpIX}

After incubation of PpIX $(10 \mu \mathrm{M})$ for $2 \mathrm{~h}$, cells were co-stained with $10 \mathrm{nM}$ Mito-Tracker Green (Beyotime, Jiangsu, China). Cells were washed twice with PBS and then observed for the sub-cellular localization of PpIX under an Olympus FV500 inverted confocal laser microscope. Fluorescence images were taken at the emission wavelength of $630 \mathrm{~nm}$ for PpIX and $520 \mathrm{~nm}$ for Mito-Tracker Green.

Measurement of cell death by Annexin V-FITC and PI staining

Cell death was determined by staining cells with Annexin V-FITC and counterstaining with propidium iodide (PI). Annexin V-FITC binds to phosphatidylserine (PS) on the outer leaflet of the plasma membrane while PI is excluded by cells with intact membranes. PI positivity including both Annexin V-FITC negative and positive is, therefore, a sign of necrosis, whereas cells positive for Annexin V-FITC, but negative for PI are generally defined as apoptotic [26]. Briefly, $0.5 \times 10^{6}$ cells were washed twice with PBS and stained with $5 \mu \mathrm{l}$ of Annexin V-FITC and $10 \mu \mathrm{l}$ of PI (BD PharMingen, San Diego, CA, USA) in $1 \times$ binding buffer (10 mM 


\section{Cellular Physiology $\quad$ Cell Physiol Biochem 2014;34:1835-1848 and Biochemistry \begin{tabular}{l|l} 
DOI: 10.1159/000366383 \\
Published online: November 21, 2014 & $\begin{array}{l}\text { O 2014 S. Karger AG, Basel } \\
\text { www.karger.com/cpb }\end{array}$ \\
\cline { 2 - 3 }
\end{tabular} Xu et al.: PpIX Induces Necrosis in Macrophages Through ROS/JNK Pathway and mPTP Opening}

HEPES, $\mathrm{pH} 7.4,140 \mathrm{mM} \mathrm{NaOH}, 2.5 \mathrm{mM} \mathrm{CaCl}_{2}$ ) for $15 \mathrm{~min}$ at room temperature in the dark. Analyses were performed using FACScan flow cytometer (BD Biosciences) and CellQuest analysis software.

\section{Measurement of intracellular and mitochondrial ROS}

The determination of intracellular oxidative stress was based on the oxidation of 2', 7'-Dichlorodihydrofluorescin diacetate (DCFH-DA), and mitochondrial ROS production was measured using MitoSOX ${ }^{\circledR}$ Red, a fluorogenic dye for highly selective detection of superoxide in the mitochondria. Cells were left untreated or pretreated with NAC, DFX, SP600125, U0126, SB203580 and then stimulated with PpIX in serum-free RMPI 1640 medium for $1 \mathrm{~h}$. After treatment, macrophages were washed with PBS and incubated with $10 \mu \mathrm{M}$ DCFH-DA or $5 \mu \mathrm{M}$ MitoSOX ${ }^{\circledR}$ Red for $20 \mathrm{~min}$. After loading the dyes, cells were washed two times with PBS and collected for flow cytometry.

\section{ATP measurement}

Intracellular ATP level was determined using a luminescence assay kit (Beyotime, Jiangsu, China) based on the procedures recommended by the manufacturer. Briefly, THP-1 macrophages were incubated with PpIX for indicated time. After incubation, cell dishes were immediately put on ice, and cells were collected and resuspended in cold PBS. About $3 \times 10^{5}$ cells were incubated with freshly prepared ATP assay mix and ATP releasing reagent, and then detected by Glomax 20/20 luminometer (Progema). The ATP level was presented as percentage to the untreated control group.

\section{LDH release assay}

LDH activity was determined in a colorimetric assay (Roche Applied Science) based on the generation of NADH by reduction of lactate and NADH-dependent conversion of iodotetrazolium chloride (INT) by diaphorase. Briefly, cells were seeded at $1 \times 10^{5} \mathrm{cells} / \mathrm{ml}$ in 96-well plate. After indicated treatment, cells were pelleted by centrifugation at $300 \times \mathrm{g}$ for $5 \mathrm{~min}$. Then, $50 \mu \mathrm{l}$ of supernatant were mixed with $50 \mu \mathrm{l}$ PBS and $100 \mu \mathrm{l}$ reaction mixture, and incubated for $30 \mathrm{~min}$ at room temperature in the dark. The reaction was stopped with $50 \mu \mathrm{l}$ of stop solution and the absorbance was recorded at $490 \mathrm{~nm}$ using a microplate reader. To assess maximal LDH activity, cells were lysed with $0.1 \%$ Triton X-100 and processed as described above. To measure basal levels of LDH release, $50 \mu \mathrm{l}$ of supernatant from cells cultured with medium only were used. The percentage of LDH release was calculated as follows: (LDH release from treated cells minus basal release) divided by (maximal LDH release minus basal release).

\section{Measurement of mitochondrial membrane potential}

Mitochondrial membrane potential $(\Delta \Psi \mathrm{m})$ was measured using a cationic fluorescent dye tetramethylrhodamine methyl ester (TMRM). TMRM is widely used to assess the changes in $\Delta \Psi \mathrm{m}$ and mitochondrial permeability transition. TMRM is readily sequestered by healthy mitochondria, but its fluorescence is rapidly lost when $\Delta \Psi \mathrm{m}$ is dissipated. After designated treatment, cells were incubated with $100 \mathrm{nM}$ TMRM for $20 \mathrm{~min}$, and were then washed two times with PBS and collected for flow cytometry.

Transmission electron microscopy

Cells were washed in PBS and fixed for 30 min with $2.5 \%$ glutaraldehyde in $0.1 \mathrm{M}$ phosphate buffer (pH 7.2). Samples were placed in 1\% osmium tetroxide and dehydrated in a graded series of ethyl alcohol, finishing with isoamyl acetate. Samples were microsectioned into ultra-thin sections, stained with uranyl acetate and lead citrate and then examined under a transmission electron microscope (JEM-1220, Japan).

\section{Preparation of Subcellular Fractions}

Freshly harvested human THP- 1 macrophages were used to determine the relative distribution of cytochrome $\mathrm{c}$ and apoptosis inducing-factor (AIF) in the cytosol and mitochondria prepared by differential centrifugation. After designated treatment, cells were washed twice with $1 \times \mathrm{PBS}$ and were resuspended in $10 \mathrm{mM} \mathrm{KCl}, 5 \mathrm{mM} \mathrm{MgCl}$, 1 mM EDTA, $1 \mathrm{mM}$ EGTA, $250 \mathrm{mM}$ sucrose, $20 \mathrm{mM}$ Hepes (pH 7.2), 0.025 \% (wt/ vol) digitonin, and protease inhibitors. After $10 \mathrm{~min}$ incubation on ice and homogenized, cell debris and nuclear fractions were removed by centrifugation at $800 \times \mathrm{g}$ for $5 \mathrm{~min}$ at $4^{\circ} \mathrm{C}$. The supernatant fraction was then subjected to centrifugation at $14,000 \times \mathrm{g}$ for $20 \mathrm{~min}$ at $4^{\circ} \mathrm{C}$, and the supernatant containing the cytosol was stored. The pellet was lysed with $1 \%$ (vol/vol) TritonX-100 in PBS for $1 \mathrm{~h}$ at $4^{\circ} \mathrm{C}$. 


\section{Cellular Physiology $\quad$ Cell Physiol Biochem 2014;34:1835-1848

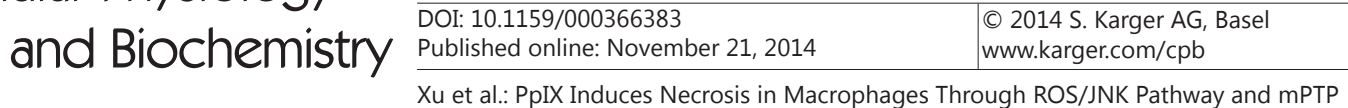 Opening}

\section{Western blotting}

After designated treatment, cells were lysed in RIPA buffer. The protein concentration was determined with a BCA kit (Beyotime, Jiangsu, China) according to the manufacturer's instructions. For western blot analysis, 20 - $50 \mu \mathrm{g}$ denatured protein was separated on SDS-PAGE gels and transferred to PVDF membranes. The membranes were blocked with 5\% skim milk in TBS for $1 \mathrm{~h}$ at room temperature on a shaking table. Then the membranes were incubated with diluted primary antibodies in TBS containing 5\% BSA and $0.1 \%$ Tween -20 at $4^{\circ} \mathrm{C}$ overnight. The membranes were washed 3 times with TBST (TBS containing 0.5\% Tween-20) for 10 min each wash, followed by re-probing with HRP-conjugated secondary antibodies at room temperature for $1 \mathrm{~h}$. Membranes were washed again 3 times with TBST for 10 min before detected using a ChemiDoc MP imaging system (Bio-Rad) and analyzed with Image Lab software (version 4.1, BioRad).

The antibody sources and dilutions used are as follows: antibodies against cytochrome $c$ (1:1000), p38 (1:1000), p-p38 (1:1000), JNK (1:1000), p-JNK (1:1000), ERK (1:1000), p-ERK (1:1000), cleavedcaspase3 (1:1000), cleaved-caspase9 (1:1000), cleaved-PARP (1:1000) were purchased from Cell Signaling Technology (Danvers, MA, USA). Antibodies against $\beta$-actin (1:5000), VDAC1 (1:800), histone (1:1000) were purchased from Proteintech Group (Wuhan, China). Apoptosis-inducing factor (AIF, 1:500) was purchased from Santa Cruz Biotechnology (Santa Cruz, CA, USA). The HRP-conjugated secondary mouse, rabbit and goat antibodies (1:5000) were purchased from ZhongShan Company (Beijing, China).

\section{Assessment of mPTP Opening by Calcein Loading/Co2+ Quenching}

The activation of $\mathrm{mPTP}$, a multi-protein channel in the inner membrane, was monitored directly in intact cells using a well-characterized calcein-AM loading $/ \mathrm{Co}^{2+}$ quenching technique by confocal microscopy [27]. Cells were loaded with $1 \mu \mathrm{M}$ calcein-AM in the dark at $37^{\circ} \mathrm{C}$ for $15 \mathrm{~min}$, in the presence of 5 $\mathrm{mM}$ cobalt chloride $\left(\mathrm{CoCl}_{2}\right)$ to quench the cytoplasmic and nuclear signals. This method allows for selective loading of calcein $(\sim 622 \mathrm{Da})$ in mitochondria with closed mPTP in living cells. After indicated treatment, cells were washed two times with Hanks' balanced salt solution-10 mM HEPES (pH 7.2) before imaging on an Olympus FV500 inverted confocal laser microscope.

\section{Statistical analysis}

Quantitative data were reported as the mean \pm SEM from at least three independent experiments. Statistical analyses were performed using SAS9.1 (SAS Institute Inc., Cary, NC). The difference between groups was determined by one-way analysis of variance (ANOVA) followed by the Bonferroni post hoc test when appropriate. Probabilities of 0.05 or less were considered to be statistically significant (2-tailed).

\section{Results}

Cytotoxicity induced by PpIX on macrophages

To test the effects of PpIX on cell viability, THP-1 macrophages were exposed to different doses of PpIX for $12 \mathrm{~h}$. The cell viability was ascertained by MTT assay. As shown in Fig. 1A, PpIX significantly reduced cell viability from $5 \mu \mathrm{M}(79.42 \pm 4.19 \%)$ to $20 \mu \mathrm{M}(46.75$ $\pm 3.47 \%$ ). Then cells were incubated with $10 \mu \mathrm{M}$ PpIX for indicated times in Fig. 1B. PpIX exposure for $6 \mathrm{~h}$ reduced cell viability to $83.52 \pm 4.69 \%$ and further to $30.80 \pm 4.24 \%$ for 48 h. Moreover, the features of cell death were observed under microscopy in Fig. 1C, including cell volume increasing, plasma membrane disintegration, cytoplasm content release and nuclei aggregation. The sub-cellular distribution of PpIX after $2 \mathrm{~h}$ incubation showed that the PpIX red fluorescence was partially corresponded with the Mito-Tracker Green fluorescence in Fig. 1D.

\section{Necrosis induced by PpIX in macrophages}

To investigate the type of cell death induced by PpIX, cell death was quantified by staining cells with Annexin V-FITC/PI. PpIX exposure induced cell death with an early loss of membrane integrity as PI-positive cells increased to $37.53 \pm 4.01 \%$ as early as $3 \mathrm{~h}$ and to $84.87 \pm 4.83 \%$ for up to $12 \mathrm{~h}$ (Fig. 2A). The Annexin V-positive/PI-negative cells were rarely 
Fig. 1. Effects of PpIX on the viability of THP-1 macrophages. (A amd B) THP-1 macrophages were exposed to PpIX at indicated concentration (0-20 $\mu \mathrm{M})$ and time (0-48 h) and cell viability was measured by MTT assays. (C) Phase-contrast images of macrophages left untreated or treated with PpIX $(10 \mu \mathrm{M})$ for $12 \mathrm{~h}$. Bar $=20 \mu \mathrm{m}$. (D) Sub-cellular localization of PpIX after $2 \mathrm{~h}$ incubation. Bar $=20 \mu \mathrm{m}$. Data are presented as the mean \pm SEM. $* P<0.05$ and $* * * P$ $<0.001$ versus the control group.
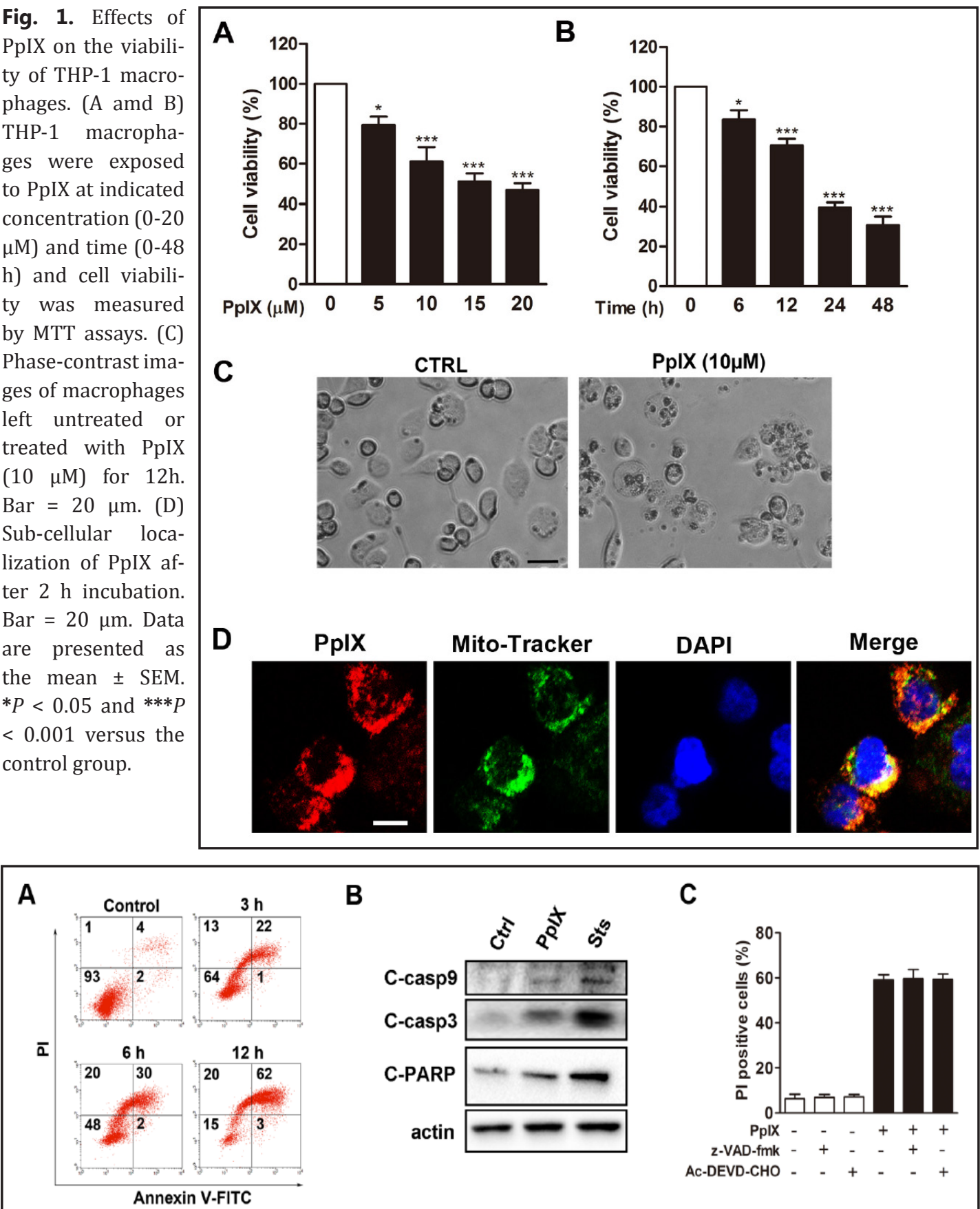

B

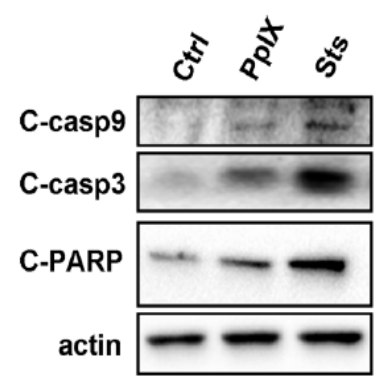

C

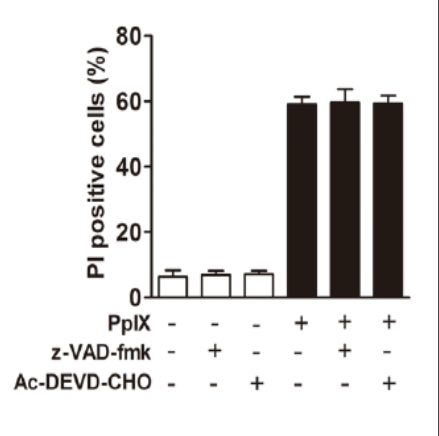

Fig. 2. Caspase-independent cell death induced by PpIX. (A) Cells were incubated with PpIX (10 $\mu \mathrm{M})$ for indicated time and assayed for phosphatidyl serine externalization and propidium iodide (PI) permeability by flow cytometry. (B) Cells were incubated with PpIX $(10 \mu \mathrm{M})$ for $6 \mathrm{~h}$. Staurosporine (STS, $1 \mu \mathrm{M})$ was used as a positive control for apoptosis. Whole cell extracts were western blotted for cleaved-caspase3, cleaved-caspase 9 and cleaved-PARP with $\beta$-actin working as loading control. (C) Cells were pretreated with broad-spectrum caspase inhibitor z-VAD-fmk $(20 \mu \mathrm{M})$ and caspase-3 specific inhibitor Ac-DEVD-CHO (10 $\mu \mathrm{M})$ before stimulated with PpIX $(10 \mu \mathrm{M})$ and examined for PI positive cells.

detected. Mild caspase- 9 and caspase- 3 activation as well as PARP cleavage were observed in PpIX-treated cells compared with staurosporine-treated cells (Fig. 2B). Furthermore, the caspase inhibitors, z-VAD-fmk (broad spectrum inhibitor) and Ac-DEVD-CHO (caspase-3 


\section{Cellular Physiology $\quad$ Cell Physiol Biochem 2014;34:1835-1848

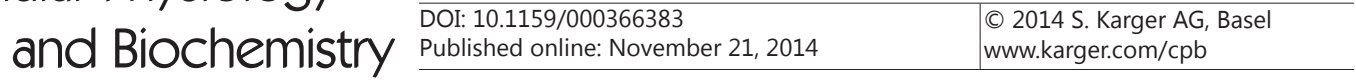 \\ Xu et al.: PpIX Induces Necrosis in Macrophages Through ROS/JNK Pathway and mPTP Opening}

Fig. 3. Necrotic features in macrophages induced by PpIX. (A) Cells were incubated with PpIX (10 $\mu \mathrm{M}$ ), and then subjected to intracellular ATP detection. (B) The supernatants were collected for LDH determination after PpIX $(10 \mu \mathrm{M})$ stimulation. (C) After treatment for indicated time, cells were collected and stained with $100 \mathrm{nM}$ tetramethylrhodamine methyl ester (TMRM) to determine the mitochondrial membrane potential $(\Delta \Psi \mathrm{m})$ by flow cytometry. Cells retained TMRM were quantified from at least three experiments. (D) Representative transmission electron microscopy of cells untreated $(\mathrm{a}, \mathrm{b})$ or treated with PpIX $(10 \mu \mathrm{M})(\mathrm{c}, \mathrm{d})$ for 12 h. Data are presented as the mean $\pm \mathrm{SEM}$. $* P<0.05, * * P<0.01$ and $* * * P<0.001$ versus the control group.

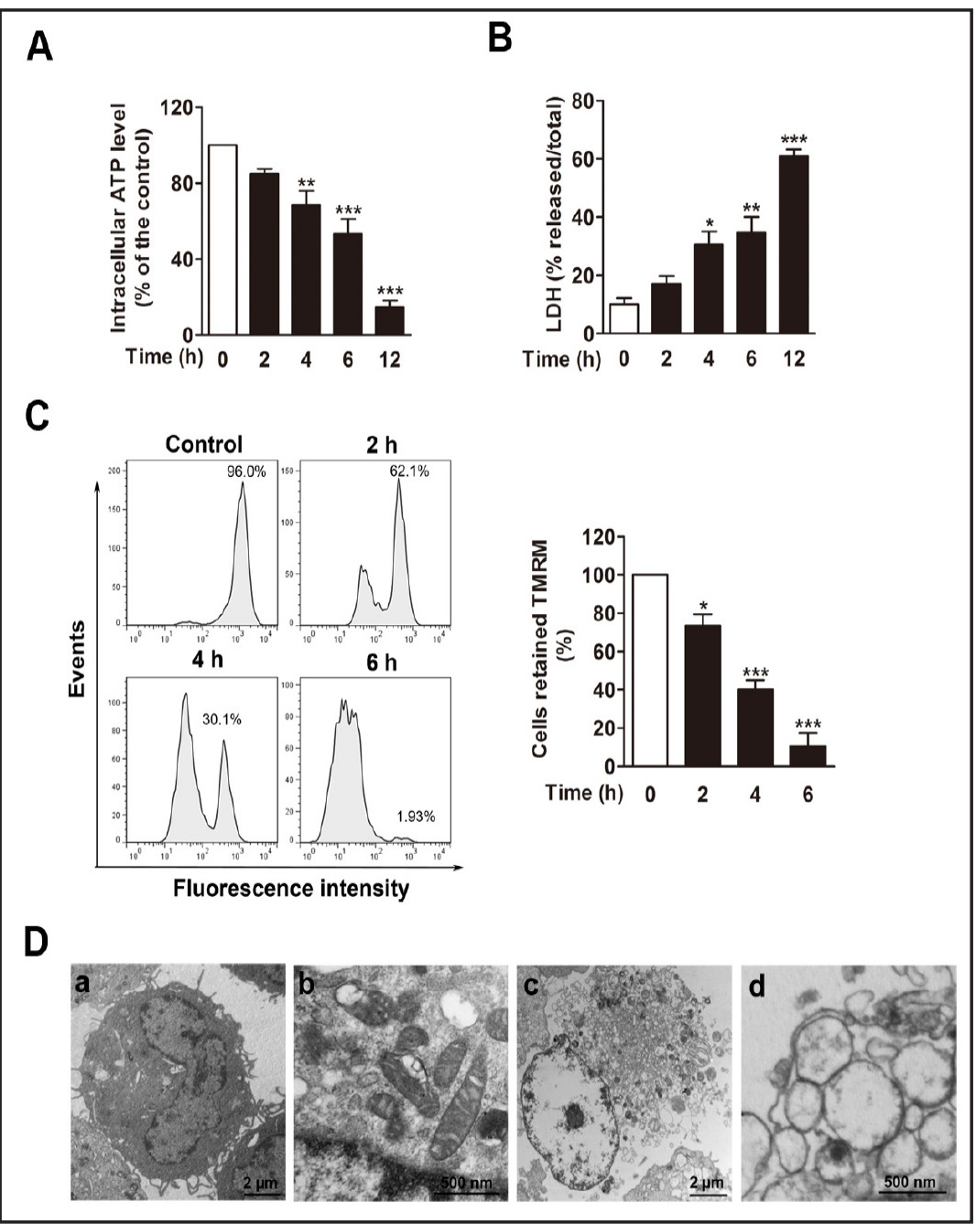

specific inhibitor) failed to prevent PpIX-induced cell death (Fig. 2C). These data show that apoptosis is unlikely the major form of cell death induced by PpIX. Concomitantly, cellular ATP depletion as well as the release of LDH was observed as early as $4 \mathrm{~h}$ (Fig. 3A and 3B) which indicate mitochondria dysfunction was involved in PpIX-induced nonapoptotic cell death. We then found that the loss of $\Delta \Psi \mathrm{m}$ occurred within $2 \mathrm{~h}$ which preceded the cell death (Fig. $3 \mathrm{C}$ ). To determine the fine ultrastructural features of cells after PpIX treatment, we performed transmission electron microscopy. Compared to the control, treated cells exhibited a necrotic morphology, including plasma membrane rupture, formation of numerous cytoplasmic vacuoles and swelling mitochondria in the absence of nuclear condensation (Fig. 3D).

\section{ROS production in PpIX-induced cell death}

As shown in Fig. 4A, significant ROS generation was detected $1 \mathrm{~h}$ after PpIX exposure as assayed by DCFH-DA staining. ROS production was blocked by ROS scavenger, $\mathrm{N}$-acetylcysteine (NAC), and iron chelator, deferoxamine (DFX). Meanwhile, mitochondrial superoxide production was also markedly increased, and was also blocked by NAC and DFX(Fig. 4B). We further found that cells pretreated with NAC and DFX were protected from the necrotic cell death induced by PpIX (Fig. 4C). To determine whether ROS acted as an upstream of mitochondrial dysfunction, we measured $\Delta \Psi \mathrm{m}$ in the absence or presence of antioxidant agents. As shown in Fig. 4D, NAC and DFX significantly abrogated PpIX-induced $\Delta \Psi$ m collapse. 


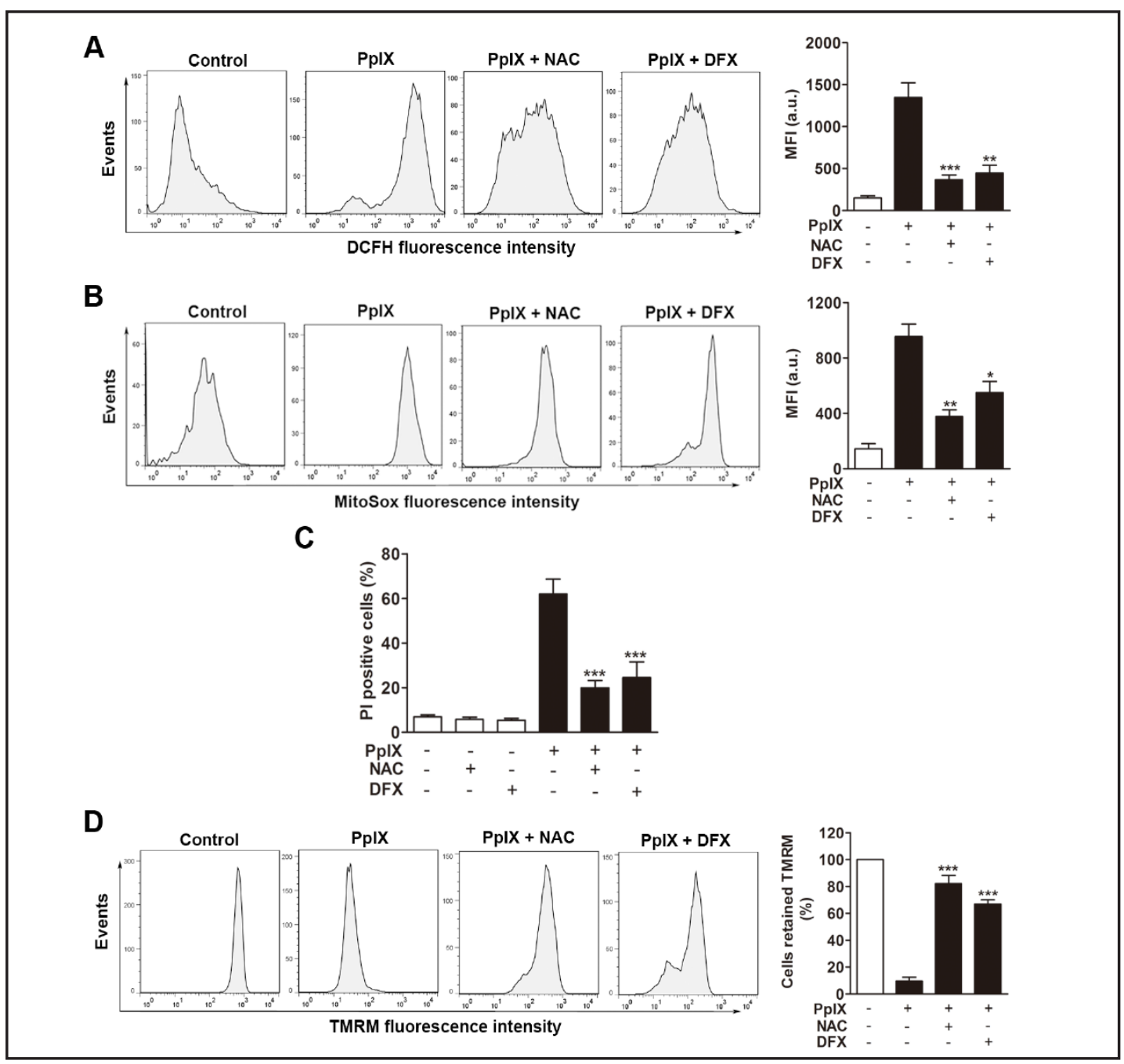

Fig. 4. ROS induction by PpIX stimulation. (A, B) Cells were left untreated or treated with N-acetylcysteine (NAC, $10 \mathrm{mM}$ ) or deferoxamine (DFX, $2 \mathrm{mM}$ ) for $2 \mathrm{~h}$ and stimulated further for $1 \mathrm{~h}$ with PpIX (10 $\mu \mathrm{M})$. Intracellular ROS production and mitochondrial superoxide generation were evaluated by flow cytometry using $10 \mu \mathrm{M}$ 2', 7'-Dichlorodihydrofluorescin diacetate (DCFH-DA) and $5 \mu \mathrm{M}$ MitoSOX ${ }^{\circledR}$ Red. (C) Cells were pretreated as in $(\mathrm{A}, \mathrm{B})$ and stimulated for $6 \mathrm{~h}$ with PpIX $(10 \mu \mathrm{M})$. The percentage of PI positive cells was quantified. (D) Cells were treated the same as (C), and $\triangle \Psi \mathrm{m}$ was measured with TMRM (100 nM). Data are presented as the mean \pm SEM. $* P<0.05, * * P<0.01$ and $* * * P<0.001$ versus the PpIX-treated group.

\section{JNK activation in PpIX-induced cell death}

As shown in Fig. 5A, stimulation of cells with PpIX resulted in the activation of the p38 and JNK, but had no dramatic effects on the activation of ERK. The phosphorylation level of p38 and JNK peaked at $4 \mathrm{~h}$ and had a tendency to decrease from 6 to $24 \mathrm{~h}$. The phosphorylation level of ERK was not altered until $4 \mathrm{~h}$ and decreased since $6 \mathrm{~h}$. We then investigated the relationship between elevated ROS and MAPKs activation. As shown in Fig. $5 \mathrm{~B}$, pretreatment of macrophages with NAC and DFX significantly inhibited p38 and JNK activation. In addition, pretreatment of cells with compounds SP600125, SB203580 and U0126, pharmacological inhibitors of JNK, p38 and ERK pathways, respectively, did not block ROS production suggesting that p38 and JNK functions as downstream of ROS (Fig. 5C). We next tested whether these signals were required for PpIX-induced cell death. Results showed that SP600125, a specific JNK inhibitor, markedly blocked cell death (Fig. 5D), whereas, SB203580 and U0126 had no effect. Inhibition of JNK by SP600125 also rescued $\Delta \Psi$ m disruption (Fig. 5E). 


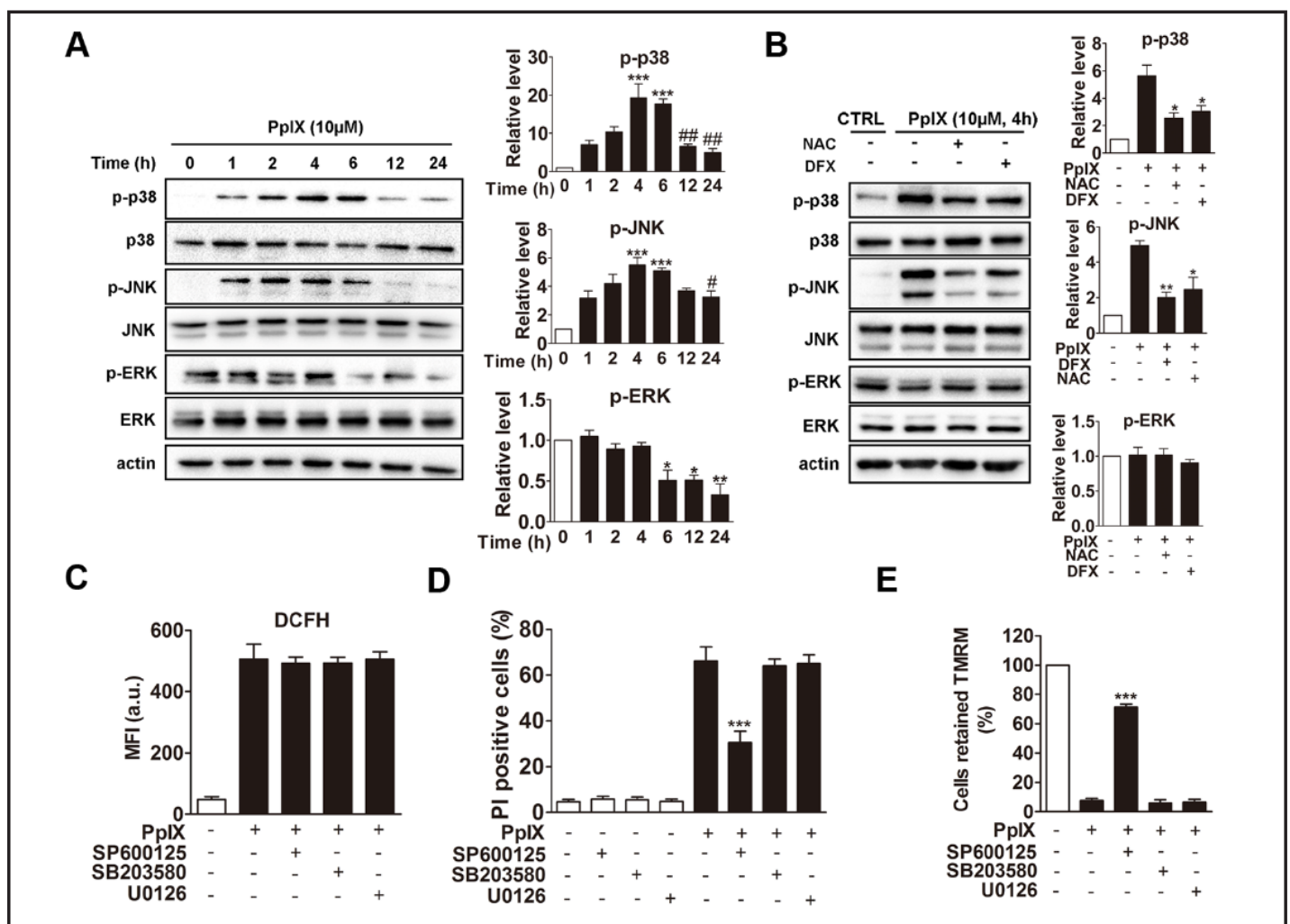

Fig. 5. JNK activation in PpIX-induced cell death. (A) Cells were stimulated with PpIX (10 $\mu \mathrm{M})$ for indicated time, and whole cell extracts were western blotted for phospho-p38, phospho-JNK and phospho-ERK as well as p38, JNK and ERK and $\beta$-actin working as loading controls. The statistical bar graph (right panel) shows the comparison of phospho-kinase levels that have been normalized to the total kinase levels. Data are presented as the mean \pm SEM. ${ }^{*} P<0.05,{ }^{* *} P<0.01$ and ${ }^{* * *} P<0.001$ versus the control group, ${ }^{\#} P<0.05$ and ${ }^{\# \#} P<$ 0.01 versus the $4 \mathrm{~h}$ group. (B) Cells were left untreated or treated with $\mathrm{N}$-acetylcysteine (NAC, $10 \mathrm{mM}$ ) or deferoxamine (DFX, $2 \mathrm{mM}$ ) for $2 \mathrm{~h}$ and stimulated further for $4 \mathrm{~h}$ with PpIX (10 $\mu \mathrm{M})$. Whole cell extracts were western blotted as in panel A. (C) Cells were pretreated with JNK inhibitor SP600125 (20 $\mu \mathrm{M})$, p38 inhibitor SB203580 $(20 \mu \mathrm{M})$, and ERK pathway inhibitor U0126 $(20 \mu \mathrm{M})$, and then stimulated with PpIX $(10 \mu \mathrm{M})$ for $2 \mathrm{~h}$ and intracellular ROS level was measured. (D) Cells were pretreated as precedingly described, and then incubated with PpIX $(10 \mu \mathrm{M})$ for $6 \mathrm{~h}$ and cell death were analyzed. (E) Cells were treated as described in panel D, then, cells were collected and $\Delta \Psi$ m was measured. Data are presented as the mean \pm SEM. $* P<0.05$, ${ }^{* *} P<0.01$ and $* * * P<0.001$ versus the PpIX-treated group.

\section{mPTP opening in PpIX-induced cell death}

The mitochondrial permeability transition pore (mPTP) has long been known as one of the main regulators of mitochondria during cell death [28]. Sudden mPTP opening under oxidative stress leads to mitochondrial matrix swelling, rupture of the outer membrane, release of intermembrane space proteins and finally necrotic cell death. We reasoned the question whether the opening of MPTP is the cause of $\Delta \Psi \mathrm{m}$ loss and cell death under PpIX exposure. We assessed the status of mPTP opening by calcein-AM loading / $\mathrm{Co}^{2+}$ quenching technique. As shown in Fig. 6A, control cells displayed distinct punctuate calcein signals in mitochondria and indicated mPTP in a closed configuration. PpIX stimulation for $6 \mathrm{~h}$ showed massive calcein fluorescence loss in mitochondria indicating mPTP opening. Pretreatment with CsA, a potent mPTP inhibitor, works by interacting with CypD, the key regulator of mPTP at the inner mitochondrial membrane, blocked PpIX-induced calcein leakage from mitochondria. CsA could also effectively block PpIX-induced necrotic cell death as well as $\Delta \Psi$ m loss (Fig. 6B and 6C). 


\section{Cellular Physiology $\quad$ Cell Physiol Biochem 2014;34:1835-1848 and Biochemistry

Fig. 6. $\mathrm{MPTP}$ opening induced by PpIX. (A) Representative confocal images of mitochondrial permeability transition pore activation by calcein $\mathrm{AM} / \mathrm{CoCl}^{2+}$ labeling. Bar $=$ $20 \mu \mathrm{m}$. (B) Cyclosporine A (CsA, $1 \mu \mathrm{M})$ was added $2 \mathrm{~h}$ prior to PpIX $(10 \mu \mathrm{M})$ stimulation and cell death were quantified. (C) Cells were treated as described in panel B. After exposure, cells were collected and $\Delta \Psi \mathrm{m}$ was evaluated. Data are presented as the mean \pm SEM. ${ }^{* *} P<0.01$ and ${ }^{* * *} P$ $<0.001$ versus the PpIXtreated group.

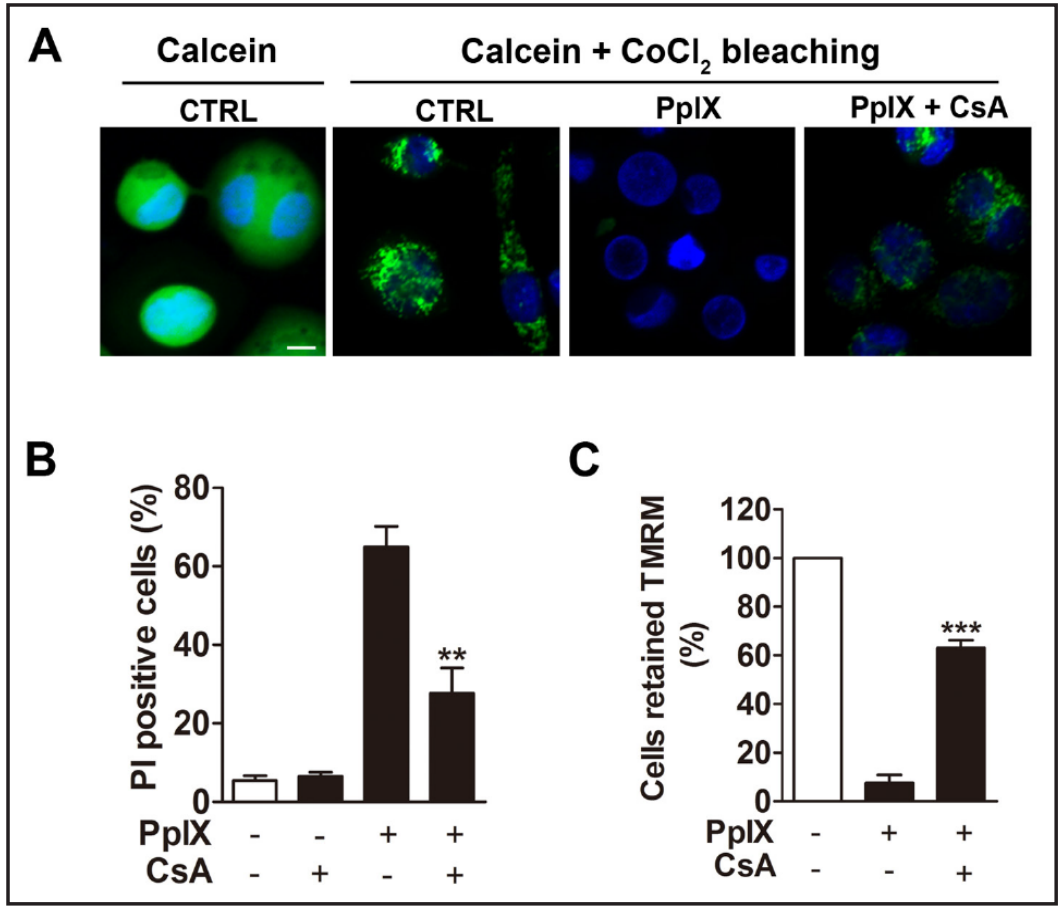

Fig. 7. Effects of ROS/JNK pathway on MPTP opening. (A) Cells were stimulated with PpIX (10 $\mu \mathrm{M})$ for indicated time, then mitochondrial and cytosolic fractions were prepared for immunoblotting against cytochrome $\mathrm{c}$ and apoptosis-inducing factor (AIF). $\beta$-actin and voltage-dependent anion channel 1 (VDAC1) were served as loading controls. (B) Cells were treated with $\mathrm{N}$-acetylcysteine (NAC, 10 mM), SP600125 $(20 \mu \mathrm{M})$ and Cyclosporine A (CsA, $1 \mu \mathrm{M})$ prior to PpIX $(10 \mu \mathrm{M})$ stimulation. Mitochondrial and cytosolic fractions were prepared and immunoblotted as in panel A. (C) Cells were pretreated with NAC $(10 \mathrm{mM})$ and SP600125 $(20 \mu \mathrm{M})$ prior to PpIX stimulation and calcein fluorescence was quantified. Data are presented as the mean \pm SEM. ${ }^{* * *} P<0.001$ versus the PpIXtreated group.

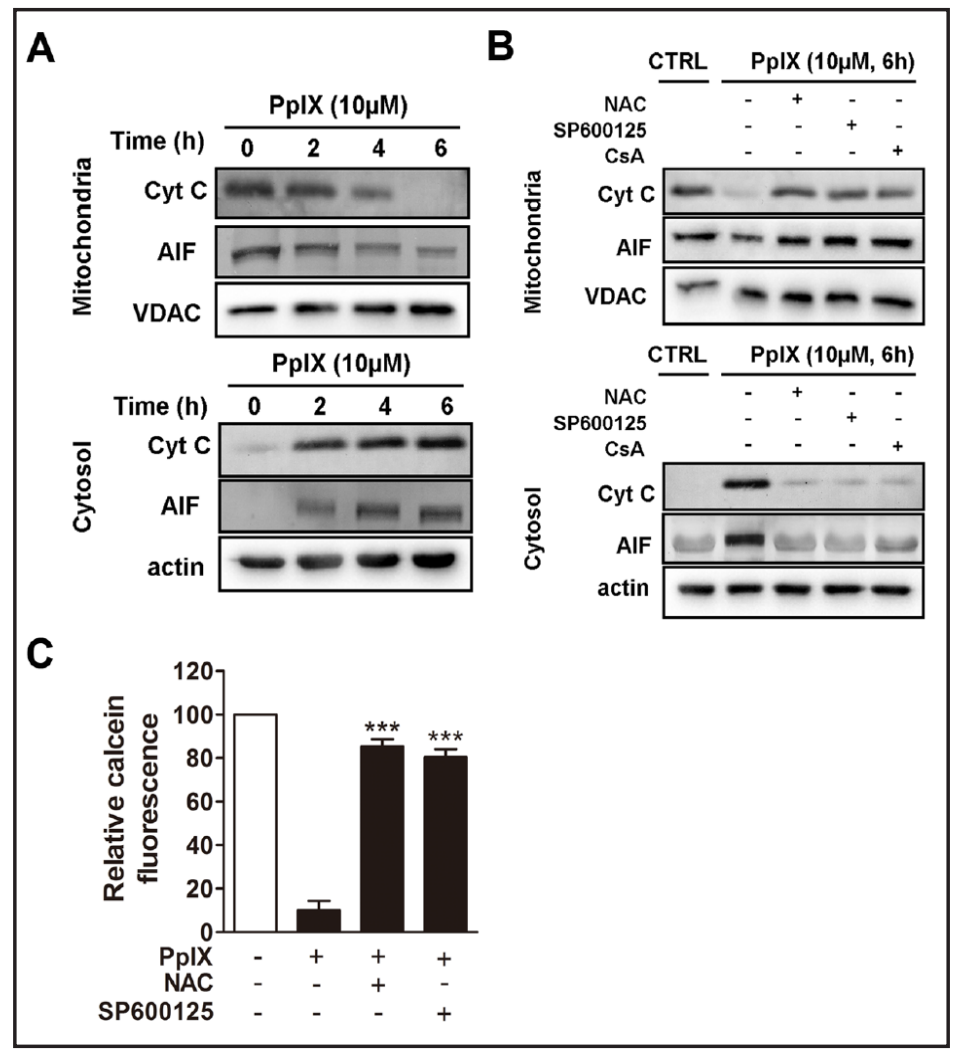

Effects of ROS/JNK pathway on mPTP opening induced by PpIX

To determine whether mPTP opening is regulated by ROS/JNK pathway, the mPTP opening was further evaluated by detecting the changes of mitochondrial intermembrane space proteins, cytochrome $\mathrm{c}$ and AIF. As shown in Fig. 7A, the amount of cytochrome $\mathrm{c}$ and AIF in the mitochondrial fractions decreased after PpIX treatment from 2 to $6 \mathrm{~h}$, meanwhile, the cytochrome c and AIF levels increased in cytosolic fractions. Thus, PpIX stimulation 
was able to induce nonspecific cytochrome $\mathrm{c}$ and AIF release from mitochondria. CsA as well as NAC and SP600125 all significantly prevented PpIX-induced cytochrome c and AIF release (Fig. 7B). NAC and SP600125 also inhibited the calcein fluorescence leakage from mitochondria (Fig. 7C). These data support that mPTP opening is regulated by ROS/JNK pathway.

\section{Discussion}

PpIX and its derivatives are widely applied in vivo and in vitro to facilitate the cell killing effects of light and ultrasound [3,4]. However, relatively little is known about the toxic effects of PpIX on cells. In this study, we investigated the mechanisms of PpIX-induced cell death in THP-1 macrophages. Our results showed that PpIX caused a dose- and time-dependent macrophage death with morphological features of necrosis including an early plasma membrane disruption, ATP loss and $\Delta \Psi$ m collapse. In addition, ROS/JNK pathway activation and subsequent mPTP opening were required for the $\Delta \Psi \mathrm{m}$ loss and cell death. Together, these results indicate that necrotic cell death of macrophages caused by PpIX is dependent on a highly regulated molecular pathway.

In response to many insults, two distinct but overlapping pathways: apoptosis and necrosis may exist. Previous studies have demonstrated that both apoptosis and necrosis could be induced by PpIX [9-11]. In our study, macrophages died with features of early loss of membrane integrity, intracellular ATP depletion and LDH release to the supernatant indicating necrosis is the major form of cell death instead of apoptosis. Besides, the necrosis is primary rather than secondary to apoptosis as less Annexin V (+) /PI (-) cells was observed and inhibition of caspases did not confer any resistance to this type of cell death. The ability of a certain agent to directly induce necrosis without the occurring of apoptosis was also demonstrated with $\mathrm{H}_{2} \mathrm{O}_{2}$ in different cell lines $[19,29]$. Interestingly, mild caspase activation was found during PpIX stimulation. Similarly results were also reported in arsenic trioxideinduced necrotic cell death in which moderate caspase 3 activation was described as a following events of the onset of necrosis [30]. It is widely established that apoptosis is an energy-dependent process. In our study, cellular energy catastrophe caused by rapid $\Delta \Psi \mathrm{m}$ loss might interfere with apoptosome formation and render the cells undergoing a necrotic fate. Therefore, our present data delineate that caspases are dispensable for induction of necrosis-like death, which is the dominant form of cell death induced by PpIX.

Here it is important to note that a significant portion of necrosis also occur through highly regulated mechanisms [31]. A considerable body of evidence has shown that ROS are main players in the propagation and execution of necrotic cell death [32, 33]. In our study, intracellular ROS as well as mitochondrial ROS was increased as early as $1 \mathrm{~h}$ after PpIX stimulation, and antioxidant NAC and iron chelator DFX significantly blocked ROS formation and cell death. This suggested that ROS production is essential in PpIX-induced necrotic cell death. As mitochondria are the major oxygen-consuming as well as ROS-forming organelles, PpIX might suppress the mitochondrial respiratory chain and disrupt the mitochondrial redox balance leading to excessive mitochondrial ROS [34]. Translocator protein (TSPO) located at the mitochondrial outer membrane might be the target of PpIX. As an endogenous ligand of TSPO, over dose of PpIX could bind to TSPO, stimulate TSPO and damage mitochondria function [35]. Furthermore, superoxide anions have been presumed as the main type of ROS produced by mitochondria [36]. Even though it is not a strong oxidant, it is the precursor of $\mathrm{H}_{2} \mathrm{O}_{2}$ which could lead to enhanced Fenton reactions producing highly reactive hydroxyl radicals [37]. The protective effects of DFX in our study might be due to the suppression of ferrous iron mediated Fenton reactions. Corresponding to our results, DFX was also shown to protect against $\mathrm{H}_{2} \mathrm{O}_{2}$-induced necrosis in L929 fibroblasts [38]. Besides, DFX was effective in rescuing heme-induced necrotic cell death by inhibiting Fenton reactions [39]. Therefore, the generation of free radicals by the Fenton reactions could be the major form of ROS during PpIX stimulation. The excessive ROS could directly oxidize critical cellular proteins, lipids and DNA or activate cell death pathways leading to mitochondrial dysfunction. Considering 
that ROS production is at the early stage of cell death before the occurrence of ATP depletion and $\Delta \Psi \mathrm{m}$ loss, we can surmise ROS production is the initial event and controls PpIX-induced necrotic cell death.

It has been well established that MAPK pathways are crucial for cellular responses to stress, especially oxidative stress, and play a critical role in the processes deciding the fate of cells $[18,40]$. Among the MAPK pathways, recent studies have highlighted the importance of JNK in regulating necrotic cell death [41]. We found that both p38 and JNK were activated after PpIX stimulation and were downstream of ROS. In addition, JNK pathway but not p38 is responsible for PpIX-induced cell death as only JNK inhibitor confers protective effects. The p38 activation is possibly a cell response to oxidative stress but not a cell death pathway. Similarly, Xu et al. also showed that both JNK and p38 are activated in necrosis and only JNK pathway is specifically required [42]. Nevertheless, the mechanism by which JNK influences necrosis remains enigmatic. It has been suggested that JNK-dependent overactivation of PARP-1 resulting in ATP depletion could lead to necrosis [19]. However, lack of protective effects of 3-amino benzamide, a specific PARP-1 inhibitor, on PpIX-induced cell death strongly indicates that PARP-1 is not responsible for this type of cell death (unpublished data). Considering the results that, inhibition of JNK significantly blocked the $\Delta \Psi \mathrm{m}$ loss, mitochondria might be the target of JNK. It is reported that JNK controlled the rapid depolarization of mitochondrial membranes in rotenone-induced H9c2 cells necrosis [43]. In other context, JNK mitochondrial translocation is responsible for mitochondrial dysfunction and eventually the necrotic cell death [44]. In our study, JNK might acts as a crosstalk between ROS production and mitochondrial dysfunction or as a direct death inducer targeting mitochondria.

Ample lines of evidence has shown that MPTP is the key executor of necrotic cell death $[45,46]$. As demonstrated in our study, PpIX could locate at mitochondria and trigger mPTP opening as the pretreatment of cells with CsA significantly inhibited $\Delta \Psi \mathrm{m}$ loss and cell death. Therefore, mPTP opening is the key event in PpIX-induced cell death. These data were consistent with the findings in previous studies, which reported severe mitochondrial injury in necrosis with MPTP opening $[21,47]$. The opening of MPTP has been reported to be regulated by several proteins, such as $\mathrm{p} 53$ and TNFR/RIP1 pathway $[24,42]$. We found that mPTP opening was regulated by ROS/JNK pathway as NAC and SP600125 suppressed mPTP opening. This could explain why the activated ROS/JNK pathway resulted in mitochondrial dysfunction. CypD, as a component of mPTP, was reported to regulate $\mathrm{Ca}^{2+}$-overload and interact with p53 in necrosis $[46,48]$. The protective effects of CsA were shown to inhibit mPTP opening by targeting CypD. Thus, it is reasonable to hypothesize that JNK interact with CypD and regulate mPTP opening under PpIX-stimulation.

In conclusion, our study first reveals that PpIX induces THP-1 macrophages death with morphological features of necrosis that is largely caspase-independent. This necrotic cell death is highly regulated by the following processes: ROS production, JNK activation, MPTP opening and finally mitochondrial dysfunction. Our results provide strategies for alleviating the adverse reactions in patients receiving porphyrin drugs and give possible explanations for the molecular signaling pathway in the toxic effects of PpIX. However, more work will be needed to demonstrate the direct interaction between PpIX and mitochondria and determine which JNK isoform, JNK1 or JNK2, is required and which part of MPTP is the direct substrate of JNK in PpIX-induced cell death.

\section{Disclosure Statement}

The authors declare that there are no conflicts of interest.

\section{Acknowledgements}

This work was supported by the National Natural Science Foundation of China $(81171483,81371709,81101164)$ and the Scientific and Technical Key Task of Heilongjiang 


\section{Cellular Physiology $\quad$ Cell Physiol Biochem 2014;34:1835-1848 and Biochemistry \begin{tabular}{l|l} 
DoI: 10.1159/000366383 & $\begin{array}{l}\text { C 2014 S. Karger AG, Basel } \\
\text { www.karger.com/cpb }\end{array}$ \\
\hline
\end{tabular} \\ Xu et al.: PpIX Induces Necrosis in Macrophages Through ROS/JNK Pathway and mPTP Opening}

Province, China (GC10C306). This work was also supported by the National key clinical specialist construction Programs of China.

\section{References}

1 Chung J, Chen C, Paw BH: Heme metabolism and erythropoiesis. Curr Opin Hematol 2012;19:156-162.

-2 Orenstein A, Kostenich G, Roitman L, Shechtman Y, Kopolovic Y, Ehrenberg B, Malik Z: A comparative study of tissue distribution and photodynamic therapy selectivity of chlorin e6, photofrin ii and ala-induced protoporphyrin ix in a colon carcinoma model. Br J Cancer 1996;73:937.

3 Li Y, Wang P, Zhao P, Zhu S, Wang X, Liu Q: Apoptosis induced by sonodynamic treatment by protoporphyrin ix on mda-mb-231 cells. Ultrasonics 2012;52:490-496.

4 Henderson BW, Busch TM, Vaughan LA, Frawley NP, Babich D, Sosa TA, Zollo JD, Dee AS, Cooper MT, Bellnier DA: Photofrin photodynamic therapy can significantly deplete or preserve oxygenation in human basal cell carcinomas during treatment, depending on fluence rate. Cancer Res 2000;60:525-529.

5 Overholt BF, Wang KK, Burdick JS, Lightdale CJ, Kimmey M, Nava HR, Sivak Jr MV, Nishioka N, Barr H, Marcon N: Five-year efficacy and safety of photodynamic therapy with photofrin in barrett's high-grade dysplasia. Gastrointest Endosc 2007;66:460-468.

6 Hendren SK, Hahn SM, Spitz FR, Bauer TW, Rubin SC, Zhu T, Glatstein E, Fraker DL: Phase ii trial of debulking surgery and photodynamic therapy for disseminated intraperitoneal tumors. Ann Surg Oncol 2001;8:65-71.

7 Bellnier DA, Greco WR, Loewen GM, Nava H, Oseroff AR, Dougherty TJ: Clinical pharmacokinetics of the pdt photosensitizers porfimer sodium (photofrin), 2- [1-hexyloxyethyl]-2-devinyl pyropheophorbide-a (photochlor) and 5-ala-induced protoporphyrin ix. Lasers Surg Med 2006;38:439-444.

-8 Bonkovsky HL, Guo JT, Hou W, Li T, Narang T, Thapar M: Porphyrin and heme metabolism and the porphyrias. Compr Physiol 2013;3:365-401.

-9 Li Q, Wang X, Zhang K, Li X, Liu Q, Wang P: DNA damage and cell cycle arrest induced by protoporphyrin ix in sarcoma 180 cells. Cell Physiol Biochem 2013;32:778-788.

10 Zawacka-Pankau J, Issaeva N, Hossain S, Pramanik A, Selivanova G, Podhajska AJ: Protoporphyrin ix interacts with wild-type p53 protein in vitro and induces cell death of human colon cancer cells in a p53dependent and-independent manner. J Biol Chem 2007;282:2466-2472.

11 Rosenberg N, Rosenberg 0, Weizman A, Veenman L, Gavish M: In vitro catabolic effect of protoporphyrin ix in human osteoblast-like cells: Possible role of the $18 \mathrm{kda}$ mitochondrial translocator protein. J Bioenerg Biomembr 2013;45:333-341.

12 Peter ME: Programmed cell death: Apoptosis meets necrosis. Nature 2011;471:310-312.

13 Golstein P, Kroemer G: Cell death by necrosis: Towards a molecular definition. Trends Biochem Sci 2007;32:37-43.

14 Finkel T: Signal transduction by reactive oxygen species. J Cell Biol 2011;194:7-15.

15 Circu ML, Aw TY: Reactive oxygen species, cellular redox systems, and apoptosis. Free Radic Biol Med 2010;48:749-762.

16 Morgan MJ, Kim Y-S, Liu Z-g: Tnf $\alpha$ and reactive oxygen species in necrotic cell death. Cell Res 2008;18:343349.

17 Morgan MJ, Liu Z-g: Crosstalk of reactive oxygen species and nf-кb signaling. Cell Res 2011;21:103-115.

18 Kamata H, Honda S-i, Maeda S, Chang L, Hirata H, Karin M: Reactive oxygen species promote tnf $\alpha$-induced death and sustained jnk activation by inhibiting map kinase phosphatases. Cell 2005;120:649-661.

19 Zhang S, Lin Y, Kim Y, Hande M, Liu Z, Shen H: C-jun n-terminal kinase mediates hydrogen peroxideinduced cell death via sustained poly (adp-ribose) polymerase-1 activation. Cell Death Differ 2007;14:1001-1010.

20 Kroemer G, Reed JC: Mitochondrial control of cell death. Nat Med 2000;6:513-519.

21 Kinnally KW, Peixoto PM, Ryu S-Y, Dejean LM: Is mptp the gatekeeper for necrosis, apoptosis, or both? Biochim Biophys Acta 2011;1813:616-622.

22 Velde CV, Cizeau J, Dubik D, Alimonti J, Brown T, Israels S, Hakem R, Greenberg A: Bnip3 and genetic control of necrosis-like cell death through the mitochondrial permeability transition pore. Mol Cell Biol 2000;20:5454-5468.

23 Whelan RS, Konstantinidis K, Wei A-C, Chen Y, Reyna DE, Jha S, Yang Y, Calvert JW, Lindsten T, Thompson CB: Bax regulates primary necrosis through mitochondrial dynamics. Proc Natl Acad Sci USA 2012;109:6566-6571.

24 Vaseva AV, Marchenko ND, Ji K, Tsirka SE, Holzmann S, Moll UM: P53 opens the mitochondrial permeability transition pore to trigger necrosis. Cell 2012;149:1536-1548. 


\section{Cellular Physiology $\quad$ Cell Physiol Biochem 2014;34:1835-1848

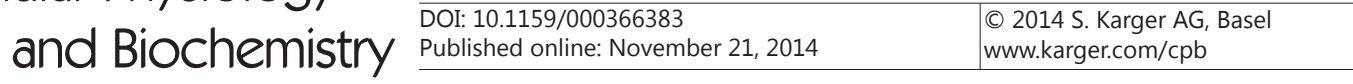 \\ Xu et al.: PpIX Induces Necrosis in Macrophages Through ROS/JNK Pathway and mPTP Opening}

25 Laskin DL, Sunil VR, Gardner CR, Laskin JD: Macrophages and tissue injury: Agents of defense or destruction? Annu Rev Pharmacol Toxicol 2011;51:267-288.

-26 Vermes I, Haanen C, Steffens-Nakken H, Reutellingsperger C: A novel assay for apoptosis flow cytometric detection of phosphatidylserine expression on early apoptotic cells using fluorescein labelled annexin v. J Immunol Methods 1995;184:39-51.

27 Petronilli V, Miotto G, Canton M, Brini M, Colonna R, Bernardi P, Di Lisa F: Transient and long-lasting openings of the mitochondrial permeability transition pore can be monitored directly in intact cells by changes in mitochondrial calcein fluorescence. Biophys J 1999;76:725-734.

28 Miura T, Tanno M: The mptp and its regulatory proteins: Final common targets of signalling pathways for protection against necrosis. Cardiovasc Res 2012;94:181-189.

-29 Matsura T, Kai M, Fujii Y, Ito H, Yamada K: Hydrogen peroxide-induced apoptosis in hl-60 cells requires caspase-3 activation. Free Radic Res 1999;30:73-83.

30 Scholz C, Wieder T, Stärck L, Essmann F, Schulze-Osthoff K, Dörken B, Daniel PT: Arsenic trioxide triggers a regulated form of caspase-independent necrotic cell death via the mitochondrial death pathway. Oncogene 2005;24:1904-1913.

-31 Cho Y, Challa S, Moquin D, Genga R, Ray TD, Guildford M, Chan FK-M: Phosphorylation-driven assembly of the rip1-rip3 complex regulates programmed necrosis and virus-induced inflammation. Cell 2009;137:1112-1123.

32 Apel K, Hirt H: Reactive oxygen species: Metabolism, oxidative stress, and signal transduction. Annu Rev Plant Biol 2004;55:373-399.

-33 Panieri E, Gogvadze V, Norberg E, Venkatesh R, Orrenius S, Zhivotovsky B: Reactive oxygen species generated in different compartments induce cell death, survival, or senescence. Free Radic Biol Med 2013;57:176-187.

-34 Turrens JF: Mitochondrial formation of reactive oxygen species. J Physiol 2003;552:335-344.

-35 Pastorino JG, Simbula G, Gilfor E, Hoek JB, Farber JL: Protoporphyrin ix, an endogenous ligand of the peripheral benzodiazepine receptor, potentiates induction of the mitochondrial permeability transition and the killing of cultured hepatocytes by rotenone. J Biol Chem 1994;269:31041-31046.

36 Murphy M: How mitochondria produce reactive oxygen species. Biochem J 2009;417:1-13.

-37 Persson HL, Yu Z, Tirosh 0, Eaton JW, Brunk UT: Prevention of oxidant-induced cell death by lysosomotropic iron chelators. Free Radic Biol Med 2003;34:1295-1305.

-38 Berghe TV, Vanlangenakker N, Parthoens E, Deckers W, Devos M, Festjens N, Guerin C, Brunk U, Declercq W, Vandenabeele P: Necroptosis, necrosis and secondary necrosis converge on similar cellular disintegration features. Cell Death Differ 2010;17:922-930.

39 Fortes GB, Alves LS, de Oliveira R, Dutra FF, Rodrigues D, Fernandez PL, Souto-Padron T, De Rosa MJ, Kelliher M, Golenbock D: Heme induces programmed necrosis on macrophages through autocrine tnf and ros production. Blood 2012;119:2368-2375.

40 Shen H-M, Liu Z-g: Ink signaling pathway is a key modulator in cell death mediated by reactive oxygen and nitrogen species. Free Radic Biol Med 2006;40:928-939.

41 Ventura J-J, Cogswell P, Flavell RA, Baldwin AS, Davis RJ: Jnk potentiates tnf-stimulated necrosis by increasing the production of cytotoxic reactive oxygen species. Genes Dev 2004;18:2905-2915.

42 Xu Y, Huang S, Liu Z-G, Han J: Poly (adp-ribose) polymerase-1 signaling to mitochondria in necrotic cell death requires rip1/traf2-mediated jnk1 activation. J Biol Chem 2006;281:8788-8795.

43 Yaglom JA, Ekhterae D, Gabai VL, Sherman MY: Regulation of necrosis of h9c2 myogenic cells upon transient energy deprivation rapid deenergization of mitochondria precedes necrosis and is controlled by reactive oxygen species, stress kinase jnk, hsp72, and arc. J Biol Chem 2003;278:50483-50496.

44 Chambers JW, Pachori A, Howard S, Iqbal S, LoGrasso PV: Inhibition of jnk mitochondrial localization and signaling is protective against ischemia/reperfusion injury in rats. J Biol Chem 2013;288:4000-4011.

45 Crompton M: The mitochondrial permeability transition pore and its role in cell death. Biochem J 1999;341:233-249.

46 Baines CP, Kaiser RA, Purcell NH, Blair NS, Osinska H, Hambleton MA, Brunskill EW, Sayen MR, Gottlieb RA, Dorn GW: Loss of cyclophilin d reveals a critical role for mitochondrial permeability transition in cell death. Nature 2005; 434:658-662.

47 Halestrap A: A pore way to die: The role of mitochondria in reperfusion injury and cardioprotection. Biochem Soc Trans 2010;38:841-860.

-48 Nakayama H, Chen X, Baines CP, Klevitsky R, Zhang X, Zhang H, Jaleel N, Chua BH, Hewett TE, Robbins J: $\mathrm{Ca} 2+$-and mitochondrial-dependent cardiomyocyte necrosis as a primary mediator of heart failure. J Clin Invest 2007;117:2431-2444. 